\title{
The First Amendment Right to Gather State-Held Information
}

The individual has long been held entitled to receive information that a willing speaker seeks to impart to him. ${ }^{1}$ This entitlement springs from fundamental democratic values and is enshrined in the First Amendment. This Note will argue for similar recognition of a right to gather information that is held by the government, ${ }^{2}$ whether or not the state wishes to disclose the information. This right also is deeply grounded in democratic values and, under the American constitutional scheme, is lodged in the First Amendment. The Note proposes a method for implementing the right to gather state-held information that is sensitive to the potential conflict between this right and the state's substantial interest under certain circumstances in withholding information.

\section{The Right to Gather Information Under Current Law}

A First Amendment right to acquire information from a voluntary source has been recognized at least as far back as the Supreme Court's 1936 decision in Grosjean v. American Press Co. ${ }^{3}$ In unanimously striking down a state tax on newspapers and other publications with large circulations, the Grosjean Court found that the tax would "limit the circulation of information to which the public is entitled in virtue of the constitutional guaranties." 4 These guarantees protect citizens' needs to exchange and acquire information..$^{5}$

1. See, e.g., Virginia State Bd. of Pharmacy v. Virginia Citizens Consumer Council, Inc., 425 U.S. 748, 756-57 (1976) (First Amendment protects recipient of information as well as advertisers); Red Lion Broadcasting Co. v. FCC, 395 U.S. 367, 386-90 (1969) ("fairness doctrine" for broadcast media upheld, in part because of public's right "to receive suitable access" to ideas and experiences); Martin v. City of Struthers, 319 U.S. 141, 143 (1943) (striking city ordinance that prohibited door-to-door solicitation because First Amendment "embraces the right to distribute literature, and necessarily protects the right to receive it") (citation omitted); Note, The Right to Know in First Amendment Analysis, 57 TEx. L. Rev. 505 (1979) (right to receive information from willing or voluntary source is well-established).

2. This Note will focus on the right to gather information from an involuntary governmental source, information that the state harbors but seeks not to disclose. The case of an involuntary private source raises many problems of its own and will not be addressed in this Note. The First Amendment has always been viewed as "a restraint on government action, not that of private persons." Columbia Broadcasting Sys., Inc. v. Democratic Nat'l Comm., 412 U.S. 94, 114 (1973).

3. 297 U.S. 233 (1936).

4. Id. at 250.

5. Id. at 243. The tax was found unconstitutional because it went "to the heart of the natural right of the members of an organized society, united for their common good, to impart and acquire information about their common interests." $I d$. 
This constitutional entitlement to receive information disseminated by a willing speaker has subsequently been recognized in a variety of circumstances and has been presumed to embrace rights of both speaker and audience, author and reader. ${ }^{6}$ This right to receive information is nonetheless a qualified right that at times has yielded to other considerations, such as national security needs and concerns over foreign policy. ${ }^{7}$

Unlike the right to receive information from a voluntary source, the right to gather information from an involuntary one has not been specifically recognized by the Court. The doctrine that has been formulated contemplates only the relative rights of the press and public; it does not explicitly recognize a First Amendment right to gather such information. ${ }^{8}$ Most recently, the existence of this right has been debated in cases involving requests for access not to written material but to physical information-a request, that is, for access to a public facility. ${ }^{9}$

In a trio of cases decided in the past six years, the Supreme Court has confronted the claims of journalists for a right to gain access to prisons. ${ }^{10}$ Because the cases involved claims for a right of access only for the press, the Court had no occasion to propose or consider a gen-

6. See note I supra (citing cases).

7. See, e.g., Kleindienst v. Mandel, 408 U.S. 753, 762.65 (1972) (citizens who wished to hear speaker properly asserted First Amendment right "to receive information and ideas," but Congress's plenary power to regulate admission or exclusion of aliens precluded weighing of right here); cf. United States v. Reynolds, 345 U.S. 1, 11 (1953) (litigant may be denied access to state-held information when government properly invokes state secrets privilege).

8. The issue of the relative access rights of the press and of the public has spawned much commentary. See, e.g., Bezanson, The New Free Press Guarantee, 63 VA. L. Rev. 731, 754-57, 786-87 (1977) (First Amendment prohibits government from restraining press access to information except for restraints generally applied and those in extraordinary circumstances); Blanchard, The Institutional Press and Its First Amendment Privileges, 1978 Sup. CT. REv. 225 (First Amendment press rights beyond those belonging to general public have not been and ought not to be recognized); Comment, The Right of the Press to Gather Information After Branzburg and Pell, 124 U. PA. L. REv, 166 (1975) (First Amendment contains protections and guarantees specific to the press including right to gather information); Note, The Right of the Press to Gather Information, 71 CoLuM. L. REv. 839 (1971) (same).

9. Houchins v. KQED, Inc., 438 U.S. 1, 3-4 (1978) (broadcast media personnel sought access to county jail); Saxbe v. Washington Post Co., 417 U.S. 843, 844-45 (1974) (new'spaper reporters sought access to federal prisons); Pell v. Procunier, 417 U.S. 817, 819-21 (1974) (newspaper reporters sought access to state prison).

10. See note 9 supra (citing cases). Although these recent access cases considered by the Supreme Court have been limited to requests to enter one kind of public facility-prisonsthe decisions have wider application. See Houchins v. KQED, Inc., 438 U.S. 1, 14 (1978) (Burger, C.J., delivering opinion of the Court) (Court's approach in prison access cases is same approach that would be used in any case in which access to public facility was requested). 
eralized right of access applicable to all citizens. ${ }^{11}$ In the first two cases, the Court failed to define the content of the press's right to gather information; it contented itself with equating the press right with that of the public. ${ }^{12}$ In so doing, the Court defined one unknown in terms of another. ${ }^{13}$ In the third case, Houchins v. KQED, Inc., ${ }^{14}$ the Court did address the extent of public access required under the Constitution, but no clear standard emerged. The Court has thus never resolved disputes concerning the existence of an individual right of access under the Constitution, ${ }^{15}$ and indeed carefully avoided a recent opportunity to do so. ${ }^{10}$ The existence and scope of this unknown right remains an open issue.

The Court's opinions in $K Q E D$, though never resolving the issue of access to information, provide explanations of a variety of approaches to the problem. In that case, reporters from the radio and television station KQED challenged a decision by county jail authorities not to allow KQED reporters to inspect and take pictures of a portion of the jail in which a prisoner had committed suicide. The reporters' First Amendment claim, which addressed only the denial of access to the press, ${ }^{17}$ charged that the jail authorities' failure to favor media representatives over the general public in giving jail tours, and their refusal to permit photographs and tape recordings during tours, violated the Constitution. ${ }^{18} \mathrm{~A}$ fragmented Court denied the claim.

11. Houchins v. KQED, Inc., 438 U.S. 1, $4-7$ (1978) (First Amendment allegations by nonmedia public not considered in trial court's injunction or court of appeals' affirmance); Saxbe v. Washington Post Co., 417 U.S. 843, 844 (1974) (suit brought only by newspaper and one of its reporters); Pell v. Procunier, 417 U.S. 817, 819 (1974) (suit brought only by journalists and prisoners).

12. In each case, the Court denied that "the Constitution imposes upon government the affirmative duty to make available to journalists sources of information not available to members of the public generally." Saxbe v. Washington Post Co., 417 U.S. 843, 850 (1974); Pell v. Procunier, 417 U.S. 817, 834 (1974).

13. See Note, The Rights of the Public and the Press to Gather Information, 87 HARv. L. REv. 1505, 1507 (1974).

14. 438 U.S. I (1978).

15. Houchins v. KQED, Inc., 438 U.S. 1, $27-28$ (1978) (Stevens, J., dissenting) (" $[T]$ he Court has never intimated that a nondiscriminatory policy of excluding entirely both the public and the press from access to information about prison conditions would avoid constitutional scrutiny.") (footnote omitted).

16. See Gannett Co. v. DePasquale, 99 S. Ct. 2898, 2911-12 (1979); cf. id. at 2918 (Rehnquist, J., concurring) (Court should reach issue of and reject First Amendment right of access).

17. The original complaint alleged that prison authorities had violated the First Amendment both by "refusing to permit media access" and by "failing to provide any effective means by which the public could be informed of conditions prevailing" in the jail. 438 U.S. at 4 . The second part of this claim was never dealt with by a court, presumably because jail officials amended their policy within three weeks of the filing of the complaint to permit regular public tours of the facility.

18. Id. at $4 \cdot 6$. 
Because none of the three opinions in $K Q E D$ commanded more than three votes, the case is best looked to for the variety of possible approaches to the level-of-access question rather than as a source of a rule itself. ${ }^{19}$ The three opinions cover the spectrum of possible positions on the right to gather information. At one end of the spectrum, Chief Justice Burger flatly denied that "the public and the media have a First Amendment right to government information regarding the conditions of jails and their inmates and presumably all other public facilities such as hospitals and mental institutions." ${ }^{20} \mathrm{He}$ found that the claimed right lacked a "discernible basis" in the Constitution and could not be translated into reasonably enforceable standards. ${ }^{21}$

Justice Stewart, concurring in $K Q E D$, took a more moderate position. ${ }^{22}$ Like the Chief Justice, he rejected a right to gather information when the government has not "open[ed] its doors." $23 \mathrm{He}$ went on, however, to suggest that the strict equality of press and public access rights previously articulated by the Court might be relaxed. ${ }^{2 \pm}$ According to Justice Stewart's theory of "flexible equal access," the "terms of access that are reasonably imposed on individual members of the public may, if they impede effective reporting without sufficient justification, be unreasonable as applied to journalists ...." ${ }^{25}$ Because under Justice Stewart's opinion the government must justify restrictions on effective access only when they are applied to the press, and even then only when the state has granted some level of access to the public generally, no public right to access is necessarily defined. The rights remain relative; their foundation and scope remain unclear.

19. The judgment of the Court in $K Q E D$ was announced by Chief Justice Burger in an opinion in which Justices White and Rehnquist joined. 438 U.S. at 3-16. Justice Stewart joined in the judgment and also delivered a concurring opinion. Id. at 16-19. Justice Stevens dissented in an opinion in which Justices Brennan and Powell joined. Id. at 19-40. Justices Marshall and Blackmun did not participate in the decision of the case.

20. Id. at 14 .

21. Id.

22. Justice Stewart's opinion is of special interest for several reasons. Most practically, this concurrence is the fulcrum of the fragile 3-1-3 holding. In addition, Justice Stewart's opinions in this and other areas have been acknowledged as a key to understanding the status of First Amendment rights. See, e.g., Nimmer, Introduction-Is Freedom of the Press a Redundancy: What Does It Add to Freedom of Speech? 26 Hastincs L.J. 639, 644 n.26 (1975). Finally, Justice Stewart was the author of the Pell and Saxbe opinions.

23. 438 U.S. at 16 (Stewart, J., concurring).

24. Id.; see Saxbe v. Washington Post Co., 417 U.S. 843,850 (1974) (articulating rule of equal access rights for press and public); Pell v. Procunier, 417 U.S. 817, 834-35 (1974) (same).

25. 438 U.S. at 17 (Stewart, J., concurring). Justice Stewart elaborated on the terms "effective reporting" and "sufficient justification" by endorsing press access with recording equipment and cameras at "reasonable times and hours." Id. at 18. Thus even journalists might be restricted by reasonable time regulations. 
Justice Stevens's dissent in KQED represents the opposite end of the spectrum from the Chief Justice's opinion and cautiously asserts a rationale for a constitutional right to gather information. Justice Stevens stated that although in prior decisions the Court had focused on discrimination between the public and the press, it had "never intimated that a nondiscriminatory policy of excluding entirely both the public and the press from access to information about prison conditions would avoid constitutional scrutiny."26 According to Justice Stevens, the Court must go b.2yond verifying that the press receives access rights equivalent to those of the general public; it must examine the level of access accorded to both press and public, ${ }^{27}$ weighing the governmental reason for denying access to the requested information against the public interest in receiving that information. ${ }^{28}$

The three opinions in KQED illustrate the present disagreement on the right to gather state-held information from an involuntary source. ${ }^{29}$ Any resolution of this conflict must meet Chief Justice Burger's challenge by demonstrating both a discernible constitutional basis for a First Amendment right to gather information and a set of practical standards for implementing that right.

\section{Doctrinal Basis of the Right to Gather Information}

Although the Supreme Court has not yet recognized a right to gather information from an unwilling source, ${ }^{30}$ the fundamental theories of government underlying the American constitutional scheme support such a right when the source is the government. The notion of a

26. Id. at 27-28 (Stevens, J, dissenting) (footnote omitted).

27. Id. at 25-26.

28. 438 U.S. at $34-38$. He concluded that in KQED there was "no legitimate penological justification for concealing from citizens the conditions in which their fellow citizens are being confined." Id. at 36 (footnote omitted). Among the potential reasons for government secrecy that were considered and dismissed by Stevens was the protection of either confidential information or the decisionmaking processes of governmental officials. Id. at 34-35. Against this governmental interest, the public interest in access to prisons was found compelling because "[n]ot only are [prisons] public institutions, financed with public funds and administered by public servants, they are an integral component of the criminal justice system," id. at 36 (footnote omitted), in which the public has a considerable and justifiable interest. Limiting his holding to the facts in the case, he struck a balance in favor of access rights of both public and press. Id. at 36-38.

29. The decision in $K Q E D$ has given rise to much commentary on the actual reach of its holding. See, e.g., Singleton \&. Hunter, Statutory and Judicial Responses to the Problem of Access to Governmental Information, 1979 DET. C. L. REv. 51, 77-87 (interpreting KQED as holding there is no individual First Amendment right of access to information); The Supreme Court, 1977 Term, 92 HARv. L. REv. 57, 178.85 (1978) (concluding KQED does not deny First Amendment public right of access to governmental facilities).

30. One commentator, however, has argued that such a right can be derived from the Court's decisions. Note, Public and Press Rights of Access to Prisoners After Branzburg and Mandel, 82 YALE L.J. 1337, 1350-53 (1973). 
citizenry's right to self-government necessarily implies a right to gather information from one's government, even when that government resists disclosure. ${ }^{31}$ Furthermore, in the American constitutional system, the right is already implicit in the guarantees of the First Amendment. ${ }^{32}$ Although this right to receive information is not absolute, it is a fundamental presumption of a system of self-government.

The core postulate of a representative democracy is that human beings are competent to govern themselves. ${ }^{33}$ Democracy rests on the

31. This Note derives the right to gather information from the individual right to participate in a representative democratic form of government. The argument is thus more specific though perhaps similar in result to the case for a generalized First Amendment "right to know." See T. Emerson, The System of Freedom of Expression 671-73 (1970) (suggesting, though not demonstrating, that First Amendment could be source of positive obligation of government to disclose information necessary for public decisionmaking); Emerson, Legal Foundations of the Right to Know, 1976 WAsH. U.L.Q. 1, 14-17 (First Amendment right to know contains right to obtain information from governmental sources). See generally H. Cross, The Public's Right to KNow (1953).

32. Because this Note addresses only access to state-held information, it does not raise privacy interests that would be implicated if private individuals were required to disclose information they wished not to reveal. Although compulsory process such as subpoena or search with a valid and lawful warrant may reach this private information, there is no private right to compulsory process or to execute lawful searches of private property attached to the individual's First Amendment right to acquire information. See U.S. Const, AMEND. IV.

Privacy interests are implicated when an individual seeks access to state-held information that the state acquired from another individual through compelled disclosure. A comprehensive theory of balancing the interests of privacy and access in such a case is beyond the scope of this Note. It is worth noting, however, that the Court has not recognized an individual right to enjoin the government from disclosing information it possesses. See Chrysler Corp. v. Brown, 441 U.S. 281, 290-94 (1979) (refusing injunction against government provision of information to claimant under Frecdom of Information Act). Furthermore, whatever privacy interests do exist on behalf of individuals from whom the government has compelled information could be protected without barring government disclosure and public access. The government has the option not to collect certain information from private citizens. 'This is not the case with information not raising these privacy issues, such as governmental agency reports or the "physical information" that can be gathered through visiting public facilities such as prisons or hospitals. In this manner, privacy is protected through limited acquisition by the state, not limited disclosure to the public. Congress has sought to limit disclosure of information pertaining to private citizens. See, e.g., 5 U.S.C. $\$ 552 a$ (1976) (requiring consent for disclosure of public record by the individual to whom the record pertains except in limited circumstances).

33. See R. DAhl, Afrer the Revolution? $35-38$ (1970). The postulate of individual political competence has been approached from a variety of directions and derives support from a number of sources. See, e.g., J. Locke, The Second Treatise of Government (T. Pcardon ed. 1952). According to Locke, the individual is, by nature, free and enters into society as a matter of choice. The state thus may excrcise authority over the individual only with his consent, a consent that he alone is capable of giving. Id. at 54-55. This abstract notion of authority based on consent has specific political consequences for the role of the individual in his polity. All power to make laws resides in the citizenry and it is only through the delegation of that authority that the state may act. The legislative power is therefore bound by the terms of the delegation given by the populace. Id. at 81 . Locke thus provides two foundations for the postulate of individual political competence: only the individual himself can consent to enter the society, and, upon entering, he himself is most competent to express his desires as to the proper limits of the state's power.

An alternative basis for the postulate can be found in the work of John Stuart Mill. 
belief that "ordinary man is more competent than anyone else to decide when and how much he shall intervene on decisions he feels are important to him," 34 to use the words of Professor Robert Dahl. Implicit in this postulate are two bases for a right to gather information from a state: first, to govern themselves, citizens have a right to all information necessary to participate fully in decisionmaking, and second, only the citizens themselves can determine the limits of their search for information.

The right to information derives from the postulate of individual political competence. State decisions in a representative democracy must be based on the alternative preferred by the greatest number. ${ }^{35}$ The state must therefore have a system to ascertain public opinion in order to fashion a public policy in accordance with that opinion. Such a system requires a process by which all are able to vote and each vote is weighted equally, ${ }^{36}$ and also requires a means to ensure that the vote itself truly expresses the preferences of the voters. ${ }^{37}$

See, e.g., J. Mill, Considerations on Representative Government (C. Shields ed. 1958). Mill suggests that any state necessarily derives its authority from the governed; no government may govern without the acceptance of its citizens and the willingness of the citizenry both to do what is necessary to preserve the state and to do what the state requires of them to carry out its goals. Id. at 6-9. Mill acknowledges that social power plays an important role in a state's exertion of authority; that is, a government may seem to govern against the wishes of the majority. He claims, however, that social power ultimately derives from the possession of a powerful idea and the ability to convince others of its rightness. The choice of government, therefore, still resides in the citizenry. Id. at 12-15. Each citizen, it follows, is more capable of determining political choices for himself than is any other individual or group. Cf. J. RAwLs, A ThEORY of Justice 233-34 (1971) (individual self-government in the form of equal political liberty is valuable for its contribution to "moral quality of civil life"; rather than being means to an end, selfgovernment itself enhances individual sense of self-worth and stabilizes just institutions).

34. R. DAHL, supra note 33, at 35 .

35. See R. Dahl, A Preface to Democratic Theory 64 (1956); Locke, supra note 33, at 73-74. A representative democracy may determine in its constitution to exalt certain rights or values such that they may not be violated even with the support of a majority at a given time. The representative body, empowered with the legislative function, thus may be limited in its actions regardless of its majority vote on certain issues. See id. at 76-81.

36. The limitations of the equal ability to vote and equal weight of each vote have not been fully appreciated in some expositions of democratic theory. See, e.g., W. KENDALL, John LOCKe AND THE DOCTRINe of MAjority-Rule 124-31 (1941) (assuming that holding popular vote is sufficient to determine will of public).

That Locke himself assumed the individual to be innately capable of determining political choices emerges from his discussion of the individual's choice to enter a political system rather than remain in the state of nature. J. Locke, supra note 33, at 70-73. Each individual can determine on his own to pursue collective security over individual security when the central responsibility of the state is the protection of private property.

37. See R. DAHL, supra note 35, at 68-69. Whether the vote alone, without more, adequately expresses individual preferences is a highly troublesome issue for contemporary democratic theory. For example, Professor Dahl wishes to distinguish the "Sovict peasant" and the "bribed stumblebum" from the individual who, voting out of enlightened selfinterest, accepts an "ideological bribe" by voting for the alternative that most benefits him personally; each, in some sense, registers a preference by voting. Although admitting 
The attainment of this congruence between true preferences and expression requires that two conditions be met. First, the alternative preferred by the individual must be among those available for selection. ${ }^{38}$ This requirement is based on the assumption that even a free and equal choice among choices that are all less desirable than a choice not on the ballot should be avoided by a representative democracy. ${ }^{30}$ Second, the congruence arises only if the individual has a full and meaningful opportunity to form his opinion. For an individual's vote truly to express his preferences, it is essential that he have available to him all information relevant to the issue. ${ }^{40}$ When the state is the sole possessor of this information, the individual's entitlement spells a governmental duty to disclose that information. By its own definition, the representative democratic state takes the will of the majority of the electorate as its policy. As part of its obligation to determine that will, the government must facilitate its accurate expression.

From this general right to receive information and from the postulate of individual political competence emerges a second basis for the individual's right to receive government-held information: only the individual himself can properly determine which state-held information he needs in order to reach a decision. If the citizen's inquiry is limited by any party other than himself, then he is not exercising the individual autonomy and self-government implied by the choice of a representative democracy. Frequently, an individual will choose not to participate in the public decisionmaking process, ${ }^{41}$ he will decide not to decide. ${ }^{42}$ If

that the former pair have expressed their preference through the ballot would render "any distinction between totalitarian and democratic systems . . . fatuous," ruling out the latter would render the search for a democratic system hopeless. Id. at 69 .

38. Id. at 70 .

39. This assumption suggests the solution to Dahl's dilemma in distinguishing the Soviet citizen's vote from a case of enlightened self-interest. The problem with treating the vote in a totalitarian state as if it expressed a preference is that the ballot may be incomplete. The vote indicates a choice among alternatives that are all less desirable than any number of other alternatives. The alternative selected under such a system need not and most often will not represent the actual preference of the electorate.

40. R. DAHL, supra note 35 , at 70 . The requirements that the preferred choice be on the ballot and that citizens have adequate information to determine preferences are coupled by Dahl in his attempt to move beyond the classical view that preference is expressed whenever choice is free. His approach is to expand this one-dimensional view by requiring that the choice be comprehensive and the electorate informed.

41. See $\mathrm{R}$. DAHL, supra note 33 , at $40-55$. The rational individual will allocate his time in such a way as to maximize his personal utility. He will thus divide his efforts among various forms of work and leisure activities, inclucling political activity. In general, he will not spend all his time either attempting to influence the public decisionmaking process or even participating in that process, but will do so only on issues of special importance to him.

42. The decision "not to decide" may also be described as a decision to accept another's judgment on a given issue, either because of indifference to the outcome or because of a conclusion that another is more competent to resolve the particular issue, or 
he chooses to seek information and to participate, however, the postulate of individual political competence implies that the individual must be able to determine how much information he needs.

If either of these decisions-the decision to participate in reaching. public choices or the decision of how much information is neededwere forced on the individual by the state, the state would be inhibiting the individual from clarifying his preferences on social issues, the precondition for expressing his political choice through his vote. The expression of the true public preference that is vital to a representative democracy would be inaccurate and thus invalid. To maintain the validity of its own system of determining the public will, the government in a representative democracy must facilitate the individual's preference formulations, and, as required, make state-held information available.

Although this requirement that the government disclose information to all individuals may appear utopian, its scope is limited because the requirement is not an absolute standard, but a goal. Even the most democratic of polities may require some level of secrecy to conduct its affairs of state, especially foreign relations. Furthermore, the state does not exist merely for the purpose of determining national will: it must use its resources for converting that will into policy and that policy into reality. A representative democracy, therefore, is not absolutely obligated to release all information at all times. There is, however, implied an individual right, albeit qualified, to gather information, which carries with it some correlative governmental duty to disclose. ${ }^{43}$

In the American system of government, this postulate of individual political competence is expressed through the concept of self-government lodged in the First Amendment. The framers of the Constitution

some combination of these two factors. See id. at 28-40. The very decision whether to decide will also require a certain level of information, though much less than active participation.

43. The nature of the qualifications that should be put on the right to gather information can be illuminated by the very goal of permitting that access. Access is not a "guarantee of cosmic rationality," R. DAHL, supra note 35 , at 70 , for the electorate; no level of access to state-held information will guarantee total knowledge of every conceivable aspect of a political question. A carefully defined right of access to state-held information will guarantee, however, that the public choice that emerges on any issue is not the result of governmental manipulation of information. The government can be accused of manipulating information if the manner in which it supplies information is intended to bring about a choice or vote other than that which would result from an electorate that possessed as much information as it wished. The absence of manipulation can be assured if information is made available in a manner that is neutral as to the identity of the claimant. The state thus might withhold certain information, for example, military secrets, so long as the entire general public was excluded and not merely certain individuals. 
intended to create a system based on individual self-government ${ }^{44}$ and understood the necessary role of public access to information in such a system. ${ }^{45}$ The Supreme Court has recognized that it is the First Amendment that enshrines the right of citizens to govern themselves. ${ }^{46}$ This right of self-government does not justify individualism to the point of anarchy and some submission to governmental commands is therefore necessary. ${ }^{47}$ To ensure that the citizen's obedience to the will of the majority is a matter of his consent rather than his forced submission, however, a system of self-government requires that he play a role in formulating governmental commands. ${ }^{48}$ For a citizen to participate fully in public affairs and for him to consent freely to be governed, he must be able to base his decisions on a complete discussion of the issues involved. To facilitate this discussion, the First Amendment ensures "that everything worth saying shall be said." ${ }_{99}$ It is the First Amend-

44. See The Federalist No. 39 (J. Madison), at 240 (C. Rossiter ed. 1961) (plan of government must be such that it recognizes the "capacity of mankind for self-government"; Constitution is defensible only insofar as it achieves this goal); THE FEDERALIST No. 1 (A. Hamilton), at 33 (C. Rossiter ed. 1961) (decision whether to adopt the Constitution is decision by the American people whether societies are capable of selecting own form of government).

45. See Proposed Bill for the More General Diffusion of Knowledge ( $T$. Jefferson), in 2 The Writings of Thomas JefFerson 220-21 (P. Ford ed. 1893) ("[W]hereas . . . experience hath shewn, that even under the best forms, those entrusted with power have, in time ... perverted it into tyranny; ... it is believed that the most effectual means of preventing this would be, to illuminate, as far as practicable, the minds of the people at large. ..."); Letter from James Madison to W.T. Barry, Aug. 4, 1822, in 9 WRitings of James Madison 103 (G. Hunt ed. 1910) ("A popular government, without popular information or the means of acquiring it, is but a prologue to a farce or a tragedy; or perhaps both. Knowledge will forever govern ignorance. And a people who mean to be their own governors, must arm themselves with the power which knowledge gives.")

46. See First Nat'l Bank of Boston v. Bellotti, 435 U.S. 765, 777 n.12 (1978) (speech protected by First Amendment is " 'more than self-expression; it is the essence of selfgovernment" ") (quoting from Garrison v. Louisiana, 379 U.S. 64, 74-75 (1964)).

47. It is important to distinguish between two different notions of self-government. Self-government could be taken to mean the right of the individual to set the bounds of his conduct in an absolutely unfettered manner. Alternatively, the notion of self-government can mean the individual surrenders some of his personal autonomy to the political authority but does so voluntarily and maintains the right and ability to participate meaningfully in the formulation of the governmental policies to which he submits. This latter notion of self-government is adopted in this Note.

48. See A. Mriklejohn, Free Speech and its Relation to Self-Government (1948). Building on his assumption that under the American form of government, "[x]ulers and ruled are the same individuals," $i d$. at 6 , Meiklejohn argues that although individuals must still obey the collective will of the society, this obedience should be the "consent of a free citizen" and not the "submission' of a slave," $i d$. at 10.

49. Id. at 25. Professor Meiklejohn's theory is one of the best discussions of the relationship between the First Amendment and self-government. His focus was on the role of the First Amendment in providing the kind of full discussion of views necessary for self-government. Meiklejohn thus saw the First Amendment as a guarantce that all responsible views on all issues would be aired and not, for example, as a guarantec that "on every occasion, every citizen shall take part in public debate." Id. 
ment, then, that contains the guarantees that are central to self-government and that is the locus of the right to gather information..$^{50}$

\section{Parameters of the Right to Gather Information}

Because the right to gather information is a presumptive, not an absolute, right, it is necessary to set boundaries that adequately accommodate recognized individual rights and justifiable state concerns. These boundaries can be derived through analogy to the doctrine of access to public forums. ${ }^{51}$

\section{A. Applicability of the Time, Place, and Manner Test}

The doctrine governing the right to assemble in public areas provides the most appropriate analogy for developing a right-of-access test because both are concerned with the use of public property for the

50. Once the First Amendment right to gather information has been recognized, a governmental duty to disclose follows for reasons beyond those of traditional representative democratic theory. Although it has been suggested that " $[t]$ he Constitution itself is neither a Freedom of Information Act nor an Official Secrets Act," Stewart, "Or of the Press," 26 Hastings L.J. 631, 636 (1975) (quoted in Houchins v. KQED, Inc., 438 U.S. 1, 14 (1978) (Burger, C.J.)), the Court has neither persuasively argued this idea nor relied on it in the holding of a case; statements of this idea can be found only as conclusory dicta. It has been held that when the government possesses a means of exercising a First Amendment right, the state may be required to furnish the facilities concerned. See Southeastern Promotions, Ltd. v. Conrad, 420 U.S. 546, 555-62 (1975) (municipal theater and private theater leased to city could not be made unavailable for showing of musical "Hair"); Hannegan v. Esquire, Inc., 327 U.S. 146, $157-59$ (1946) (postmaster may not refuse secondclass mailing privileges to nonobscene publication on claim that it fails to "meet some standard of the public good or welfare"). This requirement is seen most emphatically in cases involving the use of open public places for assembly. See generally Kalven, The Concept of the Public Forum: Cox v. Louisiana, 1965 Sup. Cr. REv. I (discussing First Amendment right to assemble in open public places). It has, howerer, been expanded beyond this setting. See L. Tribe, American Constitutional LAw 688-93 (1978) (discussing traditional public forums as well as treatment of schools and libraries as semipublic forums); Comment, Access to State-Owned Communications Media-The Public Forum Doctrine, 26 U.C.L.A. L. REv. 1410, 1432-37 (1979) (public right to use state-owned facilities that further First Amendment rights should be extended to state-owned communications media). It would be a small step to expand the doctrine to reach state-held information possessed solely by the government. If the state does not monopolize the information, it is because the information is either in the public domain and thus not in need of governmental disclosure or it is shared by the state and private citizens. In the latter case, it is the government that may be required to disclose the information; the First Amendment speaks only to the government and not to private citizens. See Columbia Broadcasting Sys., Inc. v. Democratic Nat'l Comm., 412 U.S. 94, 114 (1973) (limiting First Amendment to "a restraint on government action, not that of private persons"). It thus follows that the individual's First Amendment right to gather state-held information will, in many cases, impose a duty on the government to disclose the information sought.

51. It is easiest to envision the parameters of the right to gather information in the context of "physical information," that is, access to public facilities. The conclusions that follow, however, will be applied as well to the right to gather all types of information. 
exercise of a claimed First Amendment right. ${ }^{52}$ Both public forums and state-held information are resources that are necessary for the exercise of First Amendment rights, and resources that the government controls exclusively. The use of these resources must be open to the entire public because each individual must have the option to exercise his First Amendment rights. It is therefore not for the state, even with the support of the majority of the electorate, to regulate this usage in an arbitrary manner. The regulation of both public forums and stateheld information must allow for maximum public use with narrow limitations.

Because all public resources ultimately belong to the citizenry, restrictions on their use must serve a competing interest of the public itself. There are two major competing interests. First, there is the need for restrictions that will facilitate the use of the resource; for example, rules governing the orderly and safe use of public property are warranted. ${ }^{53}$ In the context of the First Amendment, use of resources for expression may be regulated to allow for the greatest total usage of the resource: two speeches cannot be delivered from the same soapbox at the same time. A second competing interest is the government's operational need in providing services to the public. This interest justifies restricting the use of a public resource as necessary to preserve the existence and effective functioning of the state. ${ }^{5 t}$

The goal of maximum public use within the bounds of restrictions to facilitate use and to preserve the state is common to both the use of public forums such as streets and parks and the use of state-held information. Because the "time, place, and manner" test is designed to achieve this goal in the public-forum context, so it might profitably be used in the information context as well.

52. See generally Kalven, supra note 50 (analyzing competing individual and governmental interests in public forum context); Stone, Fora Americana, 1974 SUP. Cr. REv. 233 (same). Individual justices already have suggested that a time, place, and manner analysis should be used to weigh access claims. See Houchins v. KQED, Inc., 438 U.S. 1, 17-18 (1978) (Stewart, J., concurring) (arguing for press access at reasonable times and hours); Pell v. Procunier, 417 U.S. 817, 840 (1974) (Douglas, J., dissenting) (advocating right of press to enter prisons while conceding authorities' power to "impose reasonable regulations as to the time, place, and manner of interviews to effectuate prison discipline and order").

53. Cox v. New Hampshire, 312 U.S. 569, 574 (1941) (civil liberties imply existence of an organized society; highway use may thus be regulated as public safety requires); Hague v. C.I.O., 307 U.S. 496, 515-16 (1939) (right to use public forum may be regulated to preserve peace and good order); Washington Mobilization Comm. v. Cullinane, 566 F.2d 107, 116-17 (D.C. Cir. 1977) (statute constitutionally permits police to direct demonstrators as necessary to clear passage).

54. See 5 U.S.C. $\$ 552 b$ (1976) (governmental statutory obligation to make information available does not apply in specified cases in which disclosure would impede efficient governmental functioning). 


\section{B. The Test in the Public-Forum Context}

The Supreme Court set forth explicitly its time, place, and manner test for public forums in Grayned $v$. City of Rockford.55 Grayned involved a challenge to the constitutionality of a local ordinance prohibiting "the making of any noise or diversion" on grounds adjacent to a public school "which disturbs or tends to disturb the peace or good order of such school session or class thereof." "56 In upholding the ordinance, the Court noted that reasonable time, place, and manner regulations were permissible and defined the means of evaluating these regulations:

The nature of a place, "the pattern of its normal activities, dictate the kinds of regulations of time, place, and manner that are reasonable." .. The crucial question is whether the manner of expression is basically incompatible with the normal activity of a particular place at a particular time. ${ }^{57}$

The time, place, and manner test announced in Grayned was thus, in essence, an incompatibility test. In contrast to earlier formulations of the public-forum doctrine, trustees of public property could no longer bar access solely by claiming that the property was the state's "private property," the use of which the state could regulate as it saw fit. The Grayned doctrine repudiated an approach that required public access only to areas belonging to the general public, such as streets and parks, ${ }^{58}$ while making no such requirement for the "state's property," such as prisons or libraries. ${ }^{50}$ Any such blanket "property theory" 60 of

55. 408 U.S. 104 (1972). Grayned was recently relied upon as providing the "general 'public forum' doctrine." Knights of the Ku Klux Klan v. East Baton Rouge Parish School Bd., 578 F.2d 1122, 1124 (5th Cir. 1978); cf. Connecticut State Fed'n of Teachers v. Board of Educ. Members, 538 F.2d 471, 478 (2d Cir. 1976) (citing Grayned to permit subjecting First Amendment rights to "reasonable regulation"). See generally Stone, supra note 52, at 236.56 (discussing origins and development of time, place, and manner doctrine).

56. 408 U.S. at 108. In addition to the antinoise ordinance, Grayned involved an antipicketing ordinance that prohibited picketing or demonstrating on school grounds or nearby except for the "peaceful picketing of any school involved in a labor dispute." Id. at 107. The ordinance was struck down on equal protection grounds. $I d$.

57. Id. at 116 (footnote omitted).

58. See Hague v. C.I.O., 307 U.S. 496, 515 (1939) (separate opinion of Roberts, J.) (officials cannot restrain assemblies and leafleting because "streets and parks . . . have immemorially been held in trust for the use of the public and, time out of mind, have been used for purposes of assembly, communicating thoughts between citizens and discussing public questions").

59. See, e.g., Adderly v. Florida, 385 U.S. 39 (1966) (upholding application of Florida trespass statute to demonstrators at state prison); Brown v. Louisiana, 383 U.S. 131, 16263, 166 (1966) (Black, J., dissenting) (advancing property theory to urge upholding conviction of sit-in demonstrators in library under breach of peace statute).

60. Under the "property theory" of access, the public is guaranteed access only to the 
public forum use could not stand under the Grayned test, for to be banned the access must be shown to be "incompatible with the normal activity" of the public facility. ${ }^{61}$

\section{The Test in the Right-of-Access Context}

The Grayned incompatibility test, when applied to requests for access to information,,$^{62}$ determines both the location and substance of the burden of proof.

The incompatibility test would require that the burden of proof for

property that is considered to belong to it. The right to hold a rally in a public park was thus upheld because the streets and parks "have immemorially been held in trust for the use of the public ...." Hague v. C.I.O., 307 U.S. 496,515 (1939). On the other hand, under this theory the public has no guaranteed access to property not considered to belong to it. For example, in Adderly v. Florida, 385 U.S. 39 (1966), the Court held that:

The State, no less than a private owner of property, has power to preserve the property

under its control for the use to which it is lawfully dedicated. . . The United

States Constitution does not forbid a State to control the use of its own property

for its own lawful nondiscriminatory purpose.

Id. at $47-48$.

The property theory never controlled a large number of votes on the Court. The prevailing view in Hague required three opinions to amass five votes among the seven Justices sitting on the case. Both Adderly and Brown v. Louisiana, 383 U.S. 131 (1966), were decided by $5-4$ votes with the property theory employed by the majority in the former and by the dissent in the latter. The repudiation of the theory in Grayned is all the stronger, then, because a solid majority of presencly sitting Justices joined in it. The majority opinion commanded the vote of seven Justices, and one of the two remaining Justices had rejected the property theory elsewhere; Justice Douglas joined with the majority in Brown and the dissent in Adderly, and his dissent in Grayned was unrelated to the property theory of access. 408 U.S. at 121-24 (Douglas, J., dissenting); see Stone, supra note 52 , at $251-56$.

61. 408 U.S. at 116.

62. Applying the Grayned doctrine to the access question in general and to the prison access issue specifically accords with the Court's rulings in this area. In determining the First Amendment rights of individuals to receive mail from prison inmates, the Court found that any prison regulation must further an "important or substantial governmental interest unrelated to the suppression of expression . . . [those interests including] security, order, rehabilitation." Procunier v. Martinez, 416 U.S. 396, 413-14 (1974). A similar ap. plication of the "pattern of normal activities" approach is found in Pell v. Procunier, 417 U.S. 817 (1974). The Pell Court explicitly relied on Grayned in evaluating visitation regulations in light of the prisoners' First Amendment rights. The Court cited the "normal activities" language from Grayned and noted that a prison's "'normal activity' [is the] involuntary confinement and isolation of large numbers of people." 417 U.S. at 826. It therefore held that "considerable attention . . . to the maintenance of security" was necessary and justified "the imposition of some restrictions on the entry of outsiders into the prison for face-to-face contact with inmates." Id. at 827. It is unclear why the Court did not perform a similar analysis when ruling on the claims of media plaintiffs in Pell. Secmingly satisfied to note that the media had no rights superior to those of the public, the Court did not consider the nature of the rights they did have. Id. at 829-35 (denying media plaintiffs access beyond that accorded general public).

In addition, Justice Stevens's dissent in $K Q E D$ relied on this test. 438 U.S. 1, 36 (1978) (Stevens, J., dissenting). The opinion suggested that the governmental interests would have been much stronger-and might have outweighed the First Amendment interests of the plaintiff-had they been restricted to time, place, and manner considerations. Id. 
denying access be placed squarely on the government. Before the state could limit public access to a public facility, it would have to show that the access requested would in fact be incompatible with the normal workings of that facility. The requirement recognizes that citizens have a presumptive right of access to state-held information they desire; though not always superior, the right at least exists in all instances.

This allocation of the burden of proof resolves the current uncertainty whether an absolute ban on access to a public place, if nondiscriminatory, might be valid. ${ }^{63}$ The property theory of access was the strongest basis for upholding such a ban, ${ }^{64}$ but Grayned firmly repudiated that theory. ${ }^{65}$

The substance of the burden of proof implicit in the Grayned doctrine is that the requested access must be shown to be truly incompatible with the normal activity of the facility involved. This implies two requirements: regulations of access must be narrowly drawn and must be applied without discrimination. Any restriction on access that is not extremely narrow would likely reach access that is not strictly incompatible with the facility's normal use. Any restriction on access that is discriminatory as to the claimant would necessarily be outside the type of regulation permissible under the incompatibility test. Incompatibility primarily addresses the nature of the facility or information to which access is sought; to the extent it addresses the claimant at all, it must involve neutral criteria such as the size of a group. The incompatibility test permits only narrow regulations on access that are neutrally applied. ${ }^{06}$ In so doing, the test is consistent with the require-

63. Compare Niemotko v. Maryland, 340 U.S. 268, $282-83$ (1951) (Frankfurter, J., concurring) (implying that community's regulation of speech would violate First Amendment if it constituted complete ban on use of public facilities) with Kunz v. New York, 340 U.S. 290, 298 (1951) (Jackson, J., dissenting) (conviction for conducting religious service in public area without permit should have been sustained because state has no obligation to "place its streets at [the speaker's] service to hurl insults at the passer-by") and Kovacs v. Cooper, 336 U.S. 77, $97-98$ (1949) (Jackson, J., concurring) (ordinance that "unconditionally bans all sound trucks from the city streets" does not violate First Amendment).

64. See, e.g., Adderly v. Florida, 385 U.S. 39, $47-48$ (1966); cf. note 60 supra (discussing property theory of access).

65. 408 U.S. at 116. Although the Grayned Court did not specifically address this issue of the absolute nondiscriminatory ban, the requirement that the state justify any restriction of public access implies that there is a constitutional right of the public to enter a public place unless the state can demonstrate that the entry will be incompatible with the normal activity of the place.

66. The incompatibility test requires that a denial of access be based on a showing of incompatibility with the particular facility involved. $I d$. There is thus another aspect of narrowness implied by the incompatibility test: incompatibility must be shown for the facility itself and not a genre of facilities. In this context, the incompatibility test was recently misapplied in a public forum case. Sce Dallas Ass'n of Community Organizations for Reform Now v. Dallas County Hosp. Dist., 478 F. Supp. 1250, 1255-59 (N.D. Tex. 
ment that the government not manipulate information lest it prejudice its own system of public-preference determination. ${ }^{67}$

The nature of the incompatibility test as applied to the right to gather information may be illustrated by specific applications. The test is most easily understood in the context of access to the physical information of public facilities. An individual seeking access to a prison, for example, would have a presumptive right to enter that state facility. Prison officials might exclude him from certain areas of the prison at certain times or limit the size of his party, but they could do so only upon showing that the access sought would be incompatible with the security or rehabilitative goals of the prison. More generally, in cases involving access to a public facility, the state would have to meet this rigorous burden in order to deny access. The public's right would almost always outweigh such claims as mere administrative inconvenience, ${ }^{68}$ and it would be unlikely that a minimal level of access, regulated as to time, place, and manner, could so interfere with the normal workings of a public institution as to necessitate a complete ban on any access under any circumstances. ${ }^{60}$

Application of the incompatibility test to requests for written information may be illustrated by examples drawn from two areas in which the state might want to resist disclosure and preserve secrecy: military secrets and grand jury testimony. In resisting a request to allow an individual access to sensitive military documents, the Depart-

1979) (upholding no-solicitation rule at hospital based on generalized notion of hospitals without examining if less restrictive rule allowing some access might be compatible with this specific hospital).

67. See note 43 supra (discussing constraints on government manipulation of information).

68. See L. TrIBE, supra note 50, at $686-87,689$ (state may not restrict First Amendment rights to avoid minimal inconvenience and expense); cf. Note, supra note 13, at 1521 (discussing competing individual and state interests in the context of information gathering).

69. Such minimal levels of access are already being provided by some prisons. See Houchins v. KQED, Inc., 438 U.S. 1, 4-5 (1978) (prison that wished to limit access by public did not utterly exclude public but designed tour program in keeping with security needs). A total ban on access has been upheld in the context of access to military bases, however. See Greer v. Spock, 424 U.S. 828, 834-38 (1976) (upholding constitutionality of army base regulations banning speeches and demonstrations of a partisan political nature). The result in Greer is reconcilable with the Grayned "incompatibility" test. See United States v. Douglass, 579 F.2d 545, 548-49 (9th Cir. 1978) (applying both Grayned and Greer in holding that using military base as public forum for even peaceful speeci and assembly is incompatible with its normal workings and may be banned under Grayned). Furthermore, Greer addressed the threat to a military base of bringing information into the base in the form of political speakers. It is not clear that a similar threat is raised when individuals seek to enter the base in order to gather information and bring it out. Whatever threat is raised-national security and the like-is, because of its military setting, sui generis. 
ment of Defense would be required to show that release of such information would be incompatible with the preservation of the national defense. The state in this case would bear the burden of proving that the military, by its very purpose and nature, must preserve the secrecy of the document sought. If this burden could not be met, the information would have to be provided.

Grand jury testimony is typically kept secret unless the witness testifies in the subsequent trial. ${ }^{70}$ To maintain this practice, the state would have to demonstrate that release of grand jury testimony would have such a grave impact on the grand jury system as to be incompatible with the existence of that system or of the criminal justice system generally. Such a demonstration could include evidence concerning the impact of releasing testimony on obtaining grand jury witnesses. If it could be shown that this impact would injure the operation of future grand juries, the incompatibility test would be satisfied and the information might be withheld. In general, any attempt by the state to resist disclosing information would be put to this incompatibility test.

\section{Conclusion}

A right to gather public information by entering public facilities or by gaining access to public documents should be recognized. The right is grounded in democratic theory and is specifically found in the First Amendment. Although the right is not absolute, government regulation of it must be narrow and nondiscriminatory. The state should be permitted to restrict access only upon showing that it would be incompatible with the normal activity of the public institution possessing the information sought.

70. See, e.g., 18 U.S.C. $\$ 3500$ (1976) (requiring government to produce any statement of a witness once that witness has testified). 